\title{
GOOD INTENTION ON ELECTRONIC CONTRACT THROUGH E-COMMERCE
}

\author{
Ari Purwadi \\ Law Faculty of Wijaya Kusuma University, Surabaya \\ E-mail: aripurwadi.fhuwks@gmail.com
}

\begin{abstract}
Electronic contract (e-contract) is a contract that vulnerable to the emersion of problems because the contract happened between absence persons. This problem can be avoided if businessman who included in the electronic commerce using principle of good intention. According to the Information and Electronic Transactions Act declare that good intention shall be given during the transaction taking place, it must be interpreted both in the pre-transaction stage, transaction stage, and posttransaction phase. Thus, in order to protect consumer, it's good intention should be exist in every phase of consumer transaction.
\end{abstract}

Keywords: electronic contract, good intention, consumer transaction.

\begin{abstract}
Abstrak
Kontrak elektronik adalah kontrak yang rentan terhadap kemunculan masalah karena kontrak terjadi antara orang yang tidak bertatap muka. Masalah ini dapat dihindari jika pelaku usaha termasuk dalam perdagangan elektronik menggunakan prinsip iktikad baik. Menurut Undang-Undang Informasi dan Transaksi Elektronik menyatakan iktikad baik harus diberikan selama transaksi berlangsung, harus ditafsirkan baik dalam tahap pra-transaksi, tahap transaksi, dan fase pasca-transaksi. Dengan demikian, untuk melindungi konsumen, itu iktikad baik harus ada pada setiap tahap transaksi konsumen.
\end{abstract}

Kata kunci: kontrak elektronik, iktikad baik, transaksi konsumen.

\section{Introduction}

One of technology implementation in order to enhance business competition and product selling is using electronic commerce (ecommerce) to sell various products or service, both physical and digital form. Electronic commerce (e-commerce) service allowed customer to access and made transaction everywhere. ${ }^{1} \mathrm{E}$ commerce transaction development cannot be separated from internet growth because ecommerce was ran by internet conection. One type of e-commerce transaction is business to consumer. E-commerce is an electronic business transaction made by business and consumer to fulfill particular need at particular time. In this business transaction the product's sold are various from good and services product in the form of real product or electronic pro-

Dewi Irmawati, "Pemanfaatan E-Commerce dalam Dunia Bisnis", Jurnal Ilmiah Orasi Bisnis, VI Edition, November 2011, Palembang: Business Administration Study Program of Polytechnic State Sriwijaya, page 112. duct that have been ready to be used and to be consumed. Transaction in e-commerce was made to achieve business transaction that more practices and paperless, in e-commerce transaction the actor can make transaction without face to face, thus it can be concluded that ecommerce become new inventor of new economy in technology field. The beneficial of ecommerce i.e.: For company, shorten the distance, market expansion, network expansion of business partner and efficiency, in other word it foster the service to subscriber, and the service be more responsive, also reducing the cost regarding with paper; For consumer, effective, physically secure and flexible. ${ }^{2}$

In e-commerce model, agreement reached in form of electronic contract, thus the in-

Dian Wirdasari, "Teknologi E-Commerce dalam Proses Bisnis", Jurnal Saintikom, Vol. 7 No. 2, August 2009, Medan: LPPM STMIK Triguna Dharma, page 362. 
volved parties are business and consumer. According to Act of Consumer Protection, consumers need protection in order if they get losses. Consumer losses can be classified into two group, the first loss caused by the behavior of businessmen that are irresponsibly harm to consumers, and both consumer loss resulting from unlawful acts committed by third parties, so that consumers are being misled and then harmed. The condition causes consumers position become weaker rather than businessmen position.

In e-commerce transaction there will be several problem related with consumer's rights, those are: consumer is not able to directly identifying, seeing, or fingering the items that will be ordered, unclear information about offered product and/or no certainty whether consumer has received adequate information, or which is required to take decision during transaction. Another problem is undistinctness status of law subject, from businessmen, no guarantee of transaction safety and privation also explanation toward the risks of implemented system, especially in electronic payment both credit card and electronic cash, the issue of risk imposition that is not balanced.

The next problem is that generally toward transaction on internet, the full payment has been made in advance by the consumer, meanwhile the items has not been received or will following later, the existed guarantee is items send guarantee not items received guarantee, and transaction which has characteristic borderless overbroad, it will make question about where country the legal jurisdiction of duly enacted. Part of law issue in electronic contracts are protection to consumer in e-commerce transaction and correlation between parties involved in e-commerce transaction. ${ }^{3}$

Regarding with the characteristics of ecommerce also related consumer transactions that occur from electronic contracts which arise from e-commerce, so interesting to study

Sutan Remy Syahdeini, "E-Commerce Tinjauan dari Perspektif Hukum”, Jurnal Hukum Bisnis, Vol. 12, 2001. Jakarta: Yayasan Pengembangan Hukum Bisnis (YPHB), page 19. the electronic contract through e-commerce in the perspective of consumer transaction. The concept of consumer transaction is defined as the process of consumer products shift from businessmen to consumers. Consumer concept itself is called as the user, so that a broader sense than the notion of buyers. The concept of consumer transactions occur are not necessarily the transaction (the private of contract). In this study is limited to the sale and purchase transactions through e-commerce, but still directed to transactions which conducted between ecommerce businessmen and buyers as consumers.

E-commerce consumer basically also protected by UUPK (Act of Consumer Protection), so that the rights and responsibilities which are set in UUPK is worthy to be noted. Right and responsibility are basically two correlative definition, means in a law correlation, thus a right from a party is became a responsibility for another party, and vice versa. Consumer and business rights and responsibilities in UUPK also included good intention. Good intention concept is a well known concept in civil law. Study of good intention for electronic contract in ecommerce in this paper is aimed to get understanding about the importance of good intention for consumer transaction thro-ugh e-commerce. Thus, the law issue formulated is how the good intention concept in e-commerce electronic contract?

\section{Discussion}

Business development efforts need to be done by implementing an e-commerce system. $\mathrm{E}$-commerce is carried out using internet technology. Businessmen can easily communicate and mailing through e-mail, chatting, and others. Businessmen can promote their product through online ads, also introduce their companies and looking for new subscribers (website). ${ }^{4}$ E-commerce is a conversion form from conventional commerce to data oriented com-

Siti Maryama, "Penerapan E-Commerce dalam Meningkatkan Daya Saing Usaha", Jurnal Liquidity, Vol. 2, No. 1, January-June 2013, Jakarta: STIE Ahmad Dahlan, page 78. 
merce or paperless. Michael Chissick explained general definition of e-commerce as "a broad term describing business activities with associated technical data that are conducted electronically". ${ }^{5}$ According to general definition of e-commerce, it is spreading, buying, selling, goods and services marketing through electronic system such as internet, television, world wide web (www), or others computer connection.

E-commerce also can involve electronic fund transfer, electronic data transfer, automatic inventory management system, and automatic collection data system. E-commerce itself according to Act No 11 Year 2008 about Information and Electronic Transaction (then called ITE Act) is a series of devices and electronic procedures to preparing, collecting, processing, analyzing, saving, showing, announcing, sending, and/or spreading electronic information. The activities held in the electronic system is known as electronic transaction. Electronic transaction according to ITE Act is a law action that carried out using computer, computer connection and/or other electronic media.

The understanding of consumer protecttion will be easier with the study on consumer transaction phase. Definition of consumer transaction is "process of ownership and utilization transfer of goods and/or services from businessmen to consumer". Consumer transaction phase including three phase. First, pre transaction phase. Second, consumer transaction phase. Third, past consumer transaction phase. Utilization of the implementation phase of consumer transactions in order to easily find the root problems and seek solutions.

Consumer pre transaction phase in electronic contract context is pre contract phase. Pre contract phase in business transaction to consumer, using e-commerce usually started with sell offering online in website. Mariam Darus Badrulzaman defines offer as "invitation to

Michael Chissick, 2002, Electronic Commerce Law and Practice, third edition, London: Sweet \& Maxwell, page xiv. enter into a binding agreement". ${ }^{6}$ Controversial contract in electronic contract known as the existence of offering and acceptance. The unique character of electronic contract is the use of electronic media, thus there are differences in offering and accepting mechanism. Online acceptance, reaction from offeree party to offer from offeror that is accept the offer, denial or doing contra-offer. Without acceptance to the offer there will be no contract. ${ }^{7}$ Acceptation is a willing statement to close the agreement. Acceptance to an offer usually have to be communicated to the offeror party. Acceptance commonly done by the specified way by offeror party or other way as long as it is logic.

According to consumer protection context, then consumer looking for information about the consumer products (goods and services). Consumer Information products that must be obtained by consumer is the accurate and responsible information. The consumer accurate decision of consumer product (goods and services) is very needed based on the truth of the information provided by business parties.

According to the consumer protection framework, then in promotion and advertising there are prohibition. First, prohibit to give information that misleading, confusing, and deceiving the consumer. Second, prohibit give promise has not yet been identified, use excessive words, such as a safe, harmless, containing no risks or side effects without a complete description. The businessmen have to give informative information about the consumer product offered to citizen, means the responsible and accurate information. The accuracy and good responsibility information of product has a very important meaning for consumer. This information will help consumer to choose whether buy it or not, or delay the purchase. The role of advertising is very influential towards the consumer, either mislead or provide pro-

\footnotetext{
Yahya Ahmad Zein, 2009, Kontrak Elektronik \& Penyelesaian Sengketa Bisnis E-Commerce, Bandung: Mandar Maju, page 33.

7 Rosa Agustina, "Kontrak Elektronil (e-contract) Dalam Sistem Hukum Indonesia", Gloria Juris, Vol. 8 No. 1 January-April 2008, Jakarta: Law Faculty of Unika Atma Jaya, page 9 .
} 
tection. A good ad can give verdict consideration to the consumer, while misleading it may cause harm to the consumer.

After consumer pre transaction phase, then the next transaction phase is consumer transaction or contract phase based on contract phases on law contract. Electronic contract over e-commerce is one of modern business which is non-face and non-sign. Electronic contract also knows as online contract. Edmon Makarim use the term of online contract to electronic contract and defines it as law correlation or relation that carried out in electronic way by fusing networking from computer based information system) telecommunication based information system, then it facilitated by internet global computer conection.

Electronic contract is the fundamental contract that planned, made, assigned, copied, and distributed digitally through sites in internet (website) unilaterally by the makers of the contract (in this case is the businessmen), to digitally closed also by closing the contract (in this case the consumer). Raw contract contained there in characteristics. First, electronic contract can be done for far, across countries territorial borders through internet. Second, electronic contract is faceless nature. Third, electronic contract used to transaction in various aspect, those are chattels, immovable goods, disembodied goods, and services in the form of commercial services and professional services. $^{8}$

E-contract has some characters, which are the transaction is paperless (without paper written), borderless (without geographic limit) and the party whom doing the transaction no need to face to face. E-contract is refers to all of commercial transaction based on electronic process and data transmission over electronic media. Electronic contract between e-merchant (parties who offering goods and services on internet) and e-customer (parties who buying goods and services on internet) which hap-

Johanes Ibrahim, "Reorientasi Hukum Kontrak Di Indonesia”, Jurnal Hukum Bisnis, Vol 22 No. 6, 2003, Jakarta: Yayasan Pengembangan Hukum Bisnis (YPHB), page 46. pened in internet usually done by paperless transaction, meanwhile the used of document in transaction is not paper document, but digital document). The parties on made contract have to give and ask for the fulfillment of rights and responsibilities to other party so that the fulfillment is reached. Contract is a 'document' that became a foundation and guidance to the parties involved in that agreement.

According to law contract, a contract made when there is offer and followed with acceptance. Same with the offer, then acceptance also can be done by oral or written, moreover acceptance can be done by conduct. Most countries, the legalized acceptance rule must accomplished the requirement. First, the acceptance must appropriate with terminology that delivered in offer, another method is offeree doing counter offer to the clause given. Second, acceptance must be declared during the time when the offer is still valid. Third, the desire of the offer to be bound by the agreement. ${ }^{9}$ According to Hikmahanto Juwana, contract on commercial electronic transaction has been legally valid and binding upon the buyer clicks the send button and in this case the buyer is deemed to have agreed and accepted the terms and conditions which listed on the offer. ${ }^{10}$ Agreement on the electronic transaction does not vary much with the conventional treaty agreement, only that this electronic transaction is via electronic media, the terms of any legitimately done by bidding process to happen deals. Only the "wet ink" signature which has been used in marking the agreement of the conventional trade parties replaced with a digital signature, which is a technical procedure to ensure that the parties can not "deny its existence" as the subject of law in the electronic transactions agreement. ${ }^{11}$

Rosa Agustina, op. cit., page 9.

10 Hikmahanto Juwana, "Legal Issues on E-Commerce and E-contract in Indonesia”, Jurnal Hukum Bisnis, Vol. 22 Year 2003, Jakarta: Yayasan Pengembangan Hukum Bisnis (YPHB), page 87.

11 Nining Latianingsih, “Prinsip Tanggung Jawab Pelaku Usaha Dalam Transaksi Elektronik Menurut Undang-Undang Informasi Dan Transaksi Elektronik", Jurnal Ekonomi Dan Bisnis, Vol. 11, No. 2, December 2012, Jakarta: 
Phase in this consumer transactions are usually problems that arise are about the use of standard clauses. Most transaction in this $e$ commerce, consumer do not have other choices beside to click the icon that indicates its approval over what was prudent manufacturer on its website, without any position which is quite fair for consumers to determine the content of the clause. Civil relations between the parties in electronic transactions contained in electronic documents and binding on the parties. Electronic Documents in this case must be understood as a form of parties agreement, who are not only formulated in the form of electronic agreements but also in the features which provided, such as "I agree, I accept" as a form of approval/agreement. Seeing the formulation, thus that electronic contract is a standard agreement. The use of standard contracts (agreements) there are practice where businessmen require consumers buyer agreed articles of the contract. Things like this do not always help the consumer because of the use of word in contract article made in many standard contracts form which uses terms that are not easily understood, so that made the consumer has no other choice but has to approve and accept the articles mentioned. It also caused the consumers unsuccessfully asked the improvements even if the customer rejects the contract. Attempts to make articles of online contract easily understood or which providing an explanation of the articles or highlight the most important things can be partially overcome by the technique provides a FAQ page on the website.

The next consumer transaction phase is post consumer transaction phase. In post consumer transaction phase, the transaction has occurred and its implementation has been held. This phase raises the question, namely whether there are consumer satisfaction or disappointment (dissatisfaction) of consumers. The problem that arises at this stage could happen: if the product (goods and services) that has been used the consumer does not meet the expecta-

Economic Faculty of Atma Jaya Christian University, page 73 . tions as advertised or promoted, when products (goods and services) is not in accordance with the quality of the product, either as standard in force as well as claims offender related business, after-sales service does not fit on product quality assurance (guarantee) as well as the provision of spare parts.

The contract essentially contains the rights or obligations of the promises that are given by the parties (a set of promises) that will be implemented. This is what the purpose of the contract. The contract will be made and implemented it should be legally binding valid and reflect fairness. In the electronic contract by using the consumer transaction stages to create fairness, then the main principles that should be used is good faith principle. Issues which arise in post-consumer transactions stage is the contract implementation phase which of course must use the good faith principle order that consumers are satisfied with the consumer transactions impl-ementation. Under the ITE Law also stipulated that "the parties to the Electronic Transactions good will required for the transaction in progress" (Article 17 paragraph (2) ITE act).

Regarding with contract implementation, then good intention is defined as behaviour that deserves and worth between both parties (redelijkeheid en billijkheid). Testing whether a behavior was appropriate and fair based on the norms of unwritten objective. Good intention also defined as a condition when not aware of any defects, such as payment in good intention.

In the contract there is an obligation that the contract must be performed in good intention, then the obligation is continued that the contract not only binds to what is expressly stated therein, but also to everything according to the nature of the contract, required by decency, customs, or laws (Article 1339 BW). Associated with the habit, saying that things are customarily considered forever agreed secretly inserted into the contract even though not expressly agreed (Article $1374 \mathrm{BW}$ ). Under these provisions, it can be concluded that there is a sequence of binding force of the contract. 
First, the content. Second, faith or good intention. Fourth, convention. Fifth, The act.

Germany and Dutch law contract, good intention classified into subjective good intention dan objective good intention. Good intention standard or test in contract implementation definitely is objective standard. According to law contract, the definition of action with good intention is refers to the faith of reasonable commercial standard of fair dealing, which according to Dutch legislator called as action based on redelijkheid en billijkheid (reasonableness and equity). The parties cannot act irrationally and inappropriate will not be a good defence to say that honestly believed his conduct to be reasonable and inequitable. The subjective good intention is correlates with inner attitude and psychiatric (psychische gestelheid), whether the concerned aware of or knows that his actions are contrary or not with good intention. ${ }^{12}$

Good intention in the contract execution refers to an objective good intention. Standards used in objective good intention is an objective standard that refers to an objective norm. ${ }^{13}$ The attitude of the parties in the contract must be tested based on the objective norms which unwritten which growing in society. Good intention provision refers to the unwritten norms that have become the norm of law as a legal source of its own.

The norm is said to be objective because the behaviour is not based on the assumption of the parties themselves, but such behaviour should be in accordance with the general presumption of good intention. The standard is indeed referring to the standards in force in the Roman law. Based on Roman law, good intention is an universal social norm regulating social interrelationships, i.e. every citizen has an obligation to act with good intention to all citizens. This is an objective concept which is universally applied to all transactions. This is in line with Roscoe Pound postulate: "Men must

\footnotetext{
12 Ridwan Khairandy, "Iktikad Baik dalam Pelaksanaan Kontrak: Super Eminent Principle yang Memerlukan Pengertian dan Tolok Ukur Objektif", Jurnal Hukum, No. 3 Vol 14 July 2008, Yogyakarta: Law Faculty of UII, page 354.

13 Ibid, page 354 .
}

be able to assume that those with whom they deal in the general intercourse of society will act in good faith", so that if someone act with good intention based on objective good intention standard with customary social expectation, then other people will act the same way to them. ${ }^{14}$

This is reverse with good intention concept that followed by Kanonik law which is put good intention as a moral universal norm rather than social norm. Such an approach, then bring the meaning of contextual good intention which is determined by each individual because, lest one breach a duty to God by failing or refusing to keep's promise, it is important to act reasonable to others. This is a subjective concept of good intention, which refers to a subjective moral standards because it is based on the individual honesty. ${ }^{15}$

Parties in electronic contract have their own rights and responsibilities. Business is parties that offer consumer products over the Internet, so that businesses are required to provide true and fair information on the products they offer to consumers. Business operators have the right to receive payment from consumers for goods it sells, are also entitled to obtain protection for the actions of consumers who are not well intentioned in implementing electronic contract. Consumer have obligation to pay the price of goods that have been bought from businesses according to the type of goods and the price agreed upon between businesses and consumer. Consumer are also required to fill the data of identity truthfully in the acceptance form. On the other hand, consumers are entitled to complete information on goods to be bought it. Buyers are also entitled to legal protection for acts businesses that are not well intentioned.

Good intention in the context of consumer protection is required so that the seller on electronic contracts, which offer a good product or service, provide information about the state of the real goods without guile, did not provide misleading information, while buyers

14 Ibid, page 355.
15 Ibid, page 356. 
on electronic contracts purchase the goods/services used to meet its obligations, namely to make payments.

\section{Closing}

Conclusion

According to consumer protection concept, good intention principle should be implemented not only at contract realization phase, but also at pre contract phase (consumer pra transaction phase) and contract signing phase as well (consumer transaction phase). The urgent of good intention at e-commerce electronic contract is to make the business and consumer act honestly, rationaly, and respectfuly, so that the electronic contract is not merely fulfill the formal requirements of legal certainty but also to satisfy the justice.

\section{Recommendation}

Implementation of good intention is not only in electronic contract realization, but also have to cover pre-contract phase or consumer pre-transaction. On this consumer pre-transaction phase, the candidate of consumer through e-commerce will decide whether to buy the product or not. Product seller through e-commerce have to give the right and responsible information about the product, thus the basic rights of consumer are fulfilled. The basic rights of consumer i.e: the right to be heard, right to have accurate information to the product, right to be compensated for missrepresentation shoddy goods that are inappropriate with the information given by businessmen, and right to be treated the same.

\section{References}

Agustina, Rosa. "Kontrak Elektronil (e-contract) dalam Sistem Hukum Indonesia". Gloria Juris, Vol. 8 No. 1 January-April 2008. Jakarta: Law Faculty of Atmajaya Chatolic Uiversity;

Chissick, Michael. 2002. Electronic Commerce Law and Practice, third edition, London: Sweet \& Maxwell;

Ibrahim, Johanes. "Reorientasi Hukum Kontrak Di Indonesia". Jurnal Hukum Bisnis, Vol.
22 No. 6 Year 2003- Jakarta: Yayasan Pengembangan Hukum Bisnis (YPHB);

Irmawati, Dewi. "Pemanfaatan E-Commerce dalam Dunia Bisnis", Jurnal Ilmiah Orasi Bisnis, $\mathrm{V}^{\text {th }}$ edition, November 2011. Palembang: Business Administration Study Program of Politeknik Negeri Sriwijaya;

Juwana, Hikmahanto. "Legal Issues on E-Commerce and E-contract in Indonesia". Jurnal Hukum Bisnis, Vol. 22, 2003. Jakarta: Yayasan Pengembangan Hukum Bisnis (YPHB);

Khairandy, Ridwan. "Iktikad Baik dalam Pelaksanaan Kontrak: Super Eminent Principle yang Memerlukan Pengertian dan Tolok Ukur Objektif". Jurnal Hukum, No. 3 Vol. 14 July 2008. Yogyakarta: Law Faculty of UII;

Latianingsih, Nining. "Prinsip Tanggung Jawab Pelaku Usaha Dalam Transaksi Elektronik Menurut Undang-Undang Informasi Dan Transaksi Elektronik". Jurnal Ekonomi dan Bisnis, Vol 11 No. 2, December 2012. Jakarta: Economic Faculty of Unika Atma Jaya;

Maryama, Siti."Penerapan E-Commerce Dalam Meningkatkan Daya Saing Usaha”. Jurnal Liquidity, Vol. 2, No. 1, January-June 2013. Jakarta: STIE Ahmad Dahlan;

Syahdeini, Sutan Remy. "E-Commerce Tinjauan dari Perspektif Hukum". Jurnal Hukum Bisnis, Vol. 12, 2001. Jakarta: Yayasan Pengembangan Hukum Bisnis (YPHB);

Wirdasari, Dian. "Teknologi E-Commerce dalam Proses Bisnis". Jurnal Saintikom, Medan Vol. 7, No. 2, August 2009. Medan: LPPM STMIK Triguna Dharma;

Zein, Yahya Ahmad. 2009. Kontrak Elektronik \& Penyelesaian Sengketa Bisnis E-Commerce. Bandung: Mandar Maju. 